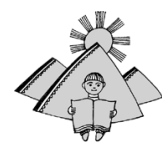

doi: 10.15330/msuc.2019.20.61-66

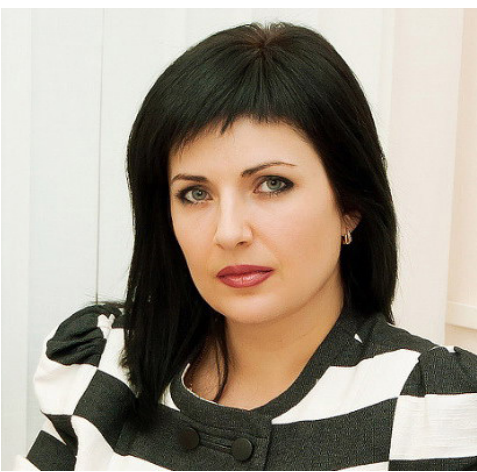

\section{Наталя Султанова,}

доктор педагогічних наук,

доцент кафедри спеціальної освіти,

Миколаївський національний університет

імені В. О. Сухомлинського

(м. Миколаїв, Україна)

\author{
Natalia Sultanova, \\ $\mathrm{PhD}$ in Education, Associate Professor, \\ Department of Natural and Mathematical Disciplines \\ and Speech Therapy, \\ Kherson State University \\ (Kherson, Ukraine) \\ sultanovanv@ukr.net \\ ORCID ID 0000-0003-3510-4662
}

УдК 373.5.016:5(477)

\title{
ОСОБЛИВОСТІ РОЗВИТКУ ЖІНОЧОЇ ОСВІТИ У НАВЧАЛЬНИХ ЗАКЛАДАХ УКРАЇНИ (ДРУГА ПОЛОВИНА ХІХ - ПОЧАТОК ХХ СТОЛІТТЯ)
}

Анотація. У публікації розкрито особливості розвитку жіночої освіти в Україні крізь призму реформаційних трансформацій в освіті у другій половині XIX - на початку XX століття. Відповідно до провідних завдань дослідження автором схарактеризовано стан шкільної освіти у цей час, передумови реформаційних змін в освіті та їх наслідки на території України. Розкрито зміст жіночої освіти в навчальних закладах країни, специфіку й напрями навчання дівчат в установах здобуття середньої освіти впродовж досліджуваного періоду.

Встановлено, що серед основних тенденцій розвитку жіночої освіти в цей час було поступове послаблення впливу церкви на діяльність навчальних закладів разом із посиленням уваги держави до гімназійної освіти; розробка нових форм і методів навчання жінок та залучення їх до професійної освіти; регламентування жіночої освіти документацією офіційного характеру (правилами, уставами, статутами, планами, положеннями, програмами та ін.) та переважанням у процесі її розвитку більш світського контексту.

Автором описано мережу, розглянуто типи навчальних закладів в України у досліджувану добу, у тому числі тих, у яких дівчата могли здобути загальну початкову та середню освіту. Засвідчено динаміку процесу відкриття жіночих гімназій та прогімназій у навчальних округах, які знаходилися на теренах України.

Особливу увагу в статті присвячено аналізу й висвітленню результатів дослідження процесу реформування системи середньої освіти. Доведено, що трансформації, які відбувалися під час реформування школи, позначалися не лише на формі, але й на змісті підготовки дівчат, а отже, й на якості загальної навчальної діяльності закладів середньої освіти.

Ключові слова: освіта, жіноча освіта, підготовка дівчат, навчальні заклади для жінок, гімназії, реформа системи освіти, історико-педагогічне дослідження.

\section{DEVELOPMENT FEATURES OF WOMEN'S EDUCATION IN UKRAINIAN EDUCATIONAL ESTABLISHMENTS (THE SECOND HALF OF THE XIX - THE BEGINNING OF THE 20TH CENTURY)}

Abstract. The peculiarities of the development of women's education in Ukraine through the prism of reforming transformations in education in the second half of the nineteenth and early twentieth centuries has been revealed in the article. In accordance with the main tasks of the research, the author has analysed the state of school education at this time, the preconditions for reforming educational changes and their implications on the territory of Ukraine. The content of female education in educational establishments of the country, specifics and directions of girls' education in institutions of secondary education during the studied period have been found out.

It has been established that among the main tendencies of the development of women's education at this time, there were the gradual easing of the church's influence on the activity of educational establishments, along with the increasing attention of the state to gymnasium education; the development of new forms and methods of training women and their involvement in vocational education; the regulation of women's education by official documentation (rules, regulations, statutes, plans, programs, etc.) and the predominance of a more secular context in the process of its development.

The author has described the system and examined the types of educational establishments in Ukraine during the studied period, including in which girls could obtain general primary and secondary education. The dynamics of the process of opening women's gymnasiums and pro-gymnasium in the educational districts that were located in Ukraine have been confirmed. 
The particular attention in the article has been devoted to the analysis and presentation of its results during the study of the process of reforming the system of secondary education. It has been proved that the transformations that took place during the reform of the school affected not only the form but also the content of the girls' preparation, and therefore the quality of the general educational activity of secondary education establishments.

Keywords: education, women's education, girls' training, educational establishments for women, gymnasium, reform of the education system, historical and pedagogical research.

\section{ВСТУП}

Постановка проблеми. В умовах реформаційних перетворень у системі сучасної освіти в Україні у вкрай важливих галузях суспільного життя, забезпеченні ґендерного балансу та рівних можливостей жінок, у тому числі в галузі освіти, виникає гостра потреба не лише в системних історико-педагогічних розвідках, але й у пошуках витоків становлення й розвитку жіночої освіти та навчальних закладів з їі надання. Це сприятиме відтворенню цілісної картини, змісту й спрямованості закладів освіти для дівчат в Україні у другій половині XIX - на початку XX століття, адже період характеризувався реформаційними зрушеннями та перетвореннями в освіті, що так само характерні у теперішній час.

Незважаючи на досягнутий прогрес сьогодні щодо врахування гендерних відмінностей у різних сферах життя суспільства, невирішеними залишаються «питання забезпечення належного рівня доступу до освіти, її якості та конкурентоспроможності в нових економічних і соціокультурних умовах» («Національна стратегія у сфері прав людини», 2015). До того ж «в Україні зберігається проблема нерівності прав та можливостей жінок і чоловіків, що зумовлює необхідність продовження активної та комплексної роботи щодо розв'язання проблем гендерної дискримінації та забезпечення реальної гендерної рівності» (там само). Пріоритет їх вирішення, у тому числі шляхом сучасних освітніх реформ, зумовлює необхідність вивчення та узагальнення теоретичного доробку і практичних надбань у галузі жіночої освіти в навчальних закладах України у другій половині XIX - на початку XX століття.

Аналіз останніх досліджень і публікацій. Зазначимо, що проблеми історії освіти, зокрема ії розвитку й особливостей реформування, становлення шкіл в Україні та функціювання навчальних закладів у різних історичних періодах були предметом вивчення сучасних учених (Г. Білавич, Л. Березовська, Б. Гершунський, Н. Дичек, Т. Завгородня, І. Зайченко, В. Кравець, В. Кузьменко, М. Левківський, Н. Побірченко, О. Сухомлинська, М. Чепіль та ін.). Науковці розкривають зміст, принципи освіти, форми й методи навчання у ретроспективі, закономірності впливу державної влади на його організацію та функціювання закладів середньої освіти в різних регіонах країни.

Жіночій освіті та навчальним закладам з її надання в Україні присвячено чимало праць вітчизняних дослідників і вчених (О. Аніщенко «Розвиток професійної жіночої освіти в Україні (друга половина XIX - початок XX століття» (2000), О. Бабіна «Становлення та розвиток гімназійної освіти в Україні (в кінці XIX - на початку XX століття» (2000), В. Вірченко «Жіночі навчальні заклади у м. Києві (1861-1920 рр.» (2006), В. Добровольська «Історія жіночої освіти Півдня України (1901-1910рр.» (2006), Л. Клевака «Навчально-виховна діяльність жіночих навчальних закладів Полтавської губернії (друга половина XIX - початок XX століття» (2014), О. Литвиненко «Жіноча середня освіта в Херсонській губернії (кінець XIX - початок XX століття» (2011), А. Сав'юк «Просвітницько-педагогічна діяльність жіночих громадських організацій на півдні України у другій половині XIX - першій чверті XX століття» (2013), Н. Слюсаренко «Становлення та розвиток трудової підготовки дівчат у школах України кінця XIX - XX століття» (2009), Т. Сухенко «Середня жіноча освіта в Україні (XIX - початок XX століття» (2001), Т. Яковишина «Організація педагогічної взаємодії у жіночих гімназіях Волині як умова соціального становлення учениць (друга половина XIX - початок XX століття» (2010) та ін.). Для ретельного аналізу проблеми дослідження використано також архівні та наративні джерела, які характеризували тодішній суспільно-політичний устрій країни, що неминуче позначався на загальноісторичному контексті освіти, специфіці її здійснення щодо жінок зокрема.

META I ЗАВДАННЯ ДОСЛІДЖЕННЯ $€$ висвітлення особливостей розвитку жіночої освіти в Україні крізь призму реформаційних трансформацій в освіті у другій половині XIX - на початку XX століття. Ключовими завданнями є аналіз та розкриття стану шкільної освіти в цей час, передумов реформаційних змін в освіті та їх наслідків на території України для різного типу навчальних закладів для дівчат.

МЕТОДИ ДОслІДЖЕНня: у процесі досягнення поставленої мети використано науково-бібліографічний метод вивчення архівних та бібліотечних фондів, історико-ретроспективний та концептуально-порівняльний аналіз літератури в галузі вітчизняної освіти, нормативно-правових документів та архівних джерел, що висвітлювали факти й теоретичні ідеї з досвіду навчання дівчат у досліджуваний час, а також проблемно-пошуковий метод.

\section{РЕЗУЛЬТАТИ ДОСЛІДЖЕННЯ}

У другій половині XIX століття значна частина України входила до складу дореволюційної Росії. Закореніла система освіти майже вичерпала свої суспільноцентричні ресурси, а тому сприяла активному пошуку нового змісту, форм та інноваційних змін. У цей час школа й освіта не задовольняли здебільшого потреби суспільства, адже станово-класовий підхід унеможливлював навчання всіх без винятку верств населення. Безкоштовним навчання було лише в початковій школі, тоді як середня й вища освіта передбачала оплату батьків. Російськомовне навчання у школах України зумовлювало складнощі в опануванні україномовними учнями навчального матеріалу, відривало від рідної культури та гальмувало їх природний розвиток, а церковна опіка, що тоді майже регламентувала весь зміст навчання, обмежувала доступ дітей і молодого покоління до сучасних наукових знань. До характерних ознак стану шкільної освіти слід додати відсутність належної матеріальної бази шкіл, низький організаційнометодичний рівень, мізерну зарплатню вчителів та їхню непідготовленість до викладання, відсутність здебільшого 
у них відповідної освіти, неприйнятні та суперечливі методи навчання (фізичне покарання, бездумне заучування матеріалу, відірваність від реального життя, навчання лише за книжками та ін.). Ці й інші проблеми в шкільній освіті, а також неузгодженість навчальних планів і програм середньої ланки освіти з професійно-технічною та вищою освітою зумовлювали необхідність початку реформаційних змін.

Слід зазначити, що «реформи в галузі освіти не передбачали створення жіночих середніх шкіл, проте вони прискорили їх створення, адже саме викладачі чоловічих середніх та вищих навчальних закладів брали активну участь в заснуванні жіночих інститутів та викладали в них» (Сухенко Т. В., 2001, с. 8).

Так, 5 березня 1856 року в Російській імперії було видано «Высочайший указ», за яким запропоновано створити в губернських містах жіночі школи, що надавали б дівчатам середню освіту. В Україні ж жіночі навчальні заклади розпочали свою безпосередню діяльність 7 січня 1860 року, коли в Києві запрацювало перше відкрите жіноче училище - Фундуклеївське, що в 1862 році було перетворене на гімназію, подібні якій відкривалися по всій території України (Полтаві, Херсоні, Чернігові). Таким чином, гімназії та прогімназії стали основними закладами середньої освіти для дівчат. У той час «гімназії являли собою восьмикласні навчальні заклади з підготовчими класами, де протягом семи років дівчата отримували загальноосвітню підготовку до вчительської діяльності. Цей клас називали педагогічним і навчання в ньому здійснювалося за спеціальним навчальним планом, затвердженим міністром народної освіти. Прогімназіями називали заклади, де курс навчання був неповним, тривав кілька років, протягом яких дівчата мали можливість закінчити три або чотири молодших класи жіночих гімназій (Слюсаренко Н. В., 2016, с. 12).

Про збільшення їх чисельності впродовж другої половини XIX століття у навчальних округах України свідчать дані, представлені в таблиці 1.

Таблиця 1

Кількість жіночих гімназій та прогімназій у Харківському, Київському й Одеському навчальних округах

\begin{tabular}{|c|c|c|c|c|c|c|}
\hline \multirow{2}{*}{ Навчальні заклади } & \multirow{2}{*}{ Рік } & \multicolumn{3}{|c|}{ Навчальний округ } & \multirow{2}{*}{$\begin{array}{c}\text { Разом } \\
\text { у 3-х } \\
\text { округах }\end{array}$} & \multirow{2}{*}{$\begin{array}{l}\text { Російська } \\
\text { імперія }\end{array}$} \\
\hline & & Харківський & Київський & Одеський & & \\
\hline \multirow[t]{2}{*}{ Гімназії } & 1881 & 14 & 9 & 15 & 38 & 100 \\
\hline & 1894 & 17 & 15 & 20 & 52 & 161 \\
\hline \multirow[t]{2}{*}{ Прогімназії } & 1881 & 35 & 14 & 21 & 70 & 178 \\
\hline & 1894 & 38 & 9 & 18 & 65 & 176 \\
\hline \multirow{2}{*}{$\begin{array}{l}\text { Загальна кількість гімназій } \\
\text { та прогімназій і відсоток, } \\
\text { який вони складали серед } \\
\text { подібних закладів Імперії }\end{array}$} & 1881 & $\begin{array}{c}49 \\
(17,6 \%)\end{array}$ & $\begin{array}{c}23 \\
(8,3 \%)\end{array}$ & $\begin{array}{c}36 \\
(12,9 \%)\end{array}$ & $\begin{array}{c}108 \\
(38,8 \%)\end{array}$ & $\begin{array}{c}278 \\
(100 \%)\end{array}$ \\
\hline & 1894 & $\begin{array}{c}55 \\
(16,4 \%)\end{array}$ & $\begin{array}{c}24( \\
7,1 \%)\end{array}$ & $\begin{array}{c}38 \\
(11,3 \%)\end{array}$ & $\begin{array}{c}117 \\
(34,7 \%)\end{array}$ & $\begin{array}{c}337 \\
(100 \%)\end{array}$ \\
\hline
\end{tabular}

Джерело: (Слюсаренко Н. В., 2016, с. 12-13).

Загальну картину розвитку жіночої освіти впродовж другої половини XIX - початку XX століття надають статистичні дані щодо динаміки збільшення числа навчальних закладів для дівчат по всій території Російської імперії (табл. 2).

Таблиця 2

Динаміка збільшення мережі жіночих гімназій і прогімназій Міністерства народної освіти у 1858-1893 рр.

\begin{tabular}{|l|l|l|l|l|}
\hline \multirow{2}{*}{ Роки } & \multicolumn{2}{|c|}{ Жіночі гімназії } & \multicolumn{2}{c|}{ Жіночі прогімназії } \\
\cline { 2 - 5 } & \multicolumn{1}{|c|}{ Кіл-ть шкіл } & \multicolumn{1}{|c|}{ Кіл-ть учнів } & \multicolumn{1}{c|}{ Кіл-ть шкіл } & Кіл-ть учнів \\
\hline 1858 & 3 & - & 2 & - \\
\hline 1861 & 20 & - & 52 & - \\
\hline 1874 & 74 & 18498 & 135 & 14652 \\
\hline 1884 & 109 & 41107 & 201 & 24557 \\
\hline 1894 & 118 & 35366 & 168 & 22506 \\
\hline 1904 & 246 & 103735 & 153 & 34289 \\
\hline 1914 & 503 & 219910 & 174 & 24128 \\
\hline
\end{tabular}

Джерело: (Днепров Э. Д., Усачева Р. Ф., 2009, с. 226-227). 
Як видно з таблиці 1, кількість жіночих прогімназій дещо переважала чисельність закладів повної середньої освіти, що свідчило про початкову орієнтацію середніх верств населення саме на прогімазійний тип жіночої школи (там само).

Слід зауважити, що на той час в Україні, включаючи гімназії і прогімназії, діяло понад 20 типів закладів середньої освіти. Серед них були установи з різним терміном навчання, конфесійні й світські школи, державні і приватні, чоловічі та жіночі. Проте «доступ жінкам до середньої освіти і вищої був обмежений. Вищі навчальні заклади діяли лише в Києві, Харкові, Одесі, Катеринославі. В жіночих середніх навчальних закладах рівень освіти був нижчим, ніж в аналогічних закладах для чоловіків» (Артемова Л. В., 2006, с. 215).

Із цих та вище акцентованих причин наприкінці XIX століття ключовим завданням діяльності урядового керівництва в галузі освіти та органів самоврядування стало введення для дітей шкільного віку загальної обов'язкової початкової освіти. У суспільстві прийшли до усвідомлення її важливості та ефективності під час наступних ланок навчання, до того ж спеціального закону про загальну обов'язкову початкову освіту ще не було.

Наслідками такого еволюційного стрибка стало розширення мережі початкових навчальних закладів, зокрема народних училищ, учні яких на основі класно-урочної форми організації навчання оволодівали знаннями з предметів (арифметика, Закон Божий, російська й церковнослов'янська мови, читання, письмо, природознавство, рукоділля для дівчат та ін.).

Окрім училищ, почали функціювати й інші загальноосвітні навчальні заклади, які відрізнялися типами, можливостями застосування нововведень або підпорядкуванням. Поширеними були міністерські, земські або міські початкові школи, сільські початкові школи, школи грамоти, народні, церковнопарафіяльні училища, однокласні та двокласні початкові училища та інші заклади, зміст і характер навчання в яких, а також обсяг і предмети різнились. Відповідно, й затребуваність серед населення цих установ була не однаковою. На розгортання мережі закладів загального початкового навчання збільшувалося асигнування держави. Передбачалося охопити в першу чергу тих дітей (зокрема дівчат), які не мали можливості відвідувати школу. Таким чином, стара система освіти почала трансформуватися та пристосовуватися до нових реформаційних змін.

Таких змін у 90-х роках зазнає й зміст та методологія освіти дітей. «Все частіше у школах стали використовуватися активні методи навчання - бесіди, розповіді вчителів, екскурсії на природу, на виробництво» (Артемова Л. В., 2006, с. 26). Проте окремі реформаційні наслідки мали й експерименти в процесі розвитку жіночої середньої освіти ще з кінця 1850-х років до 1870-х. Результатами реформ у жіночій освіті стали:

• «створення відкритої всестанової середньої жіночої школи, що істотно розширило і демократизувало жіночу освіту;

- формування переважної частини жіночої освіти у вигляді міністерських гімназій та прогімназій як суспільно-державних, перш за все за типом фінансування і характеру управління навчальними закладами;

- проведення ідеї єдності та наступності в системі жіночої освіти, яка встановила, з одного боку, безпосередній зв'язок між жіночими гімназіями та прогімназіями, між повною та неповною жіночою середньою школою, а з іншого - їх зв'язок з початковою освітою;

- значне посилення навчального курсу жіночих гімназій, який максимально наблизився до чоловічої середньої освіти;

• випускниці жіночих навчальних закладів отримали змогу займатися педагогічною діяльністю, що зробило жіночу школу важливим фактором розвитку початкової школи, підготувавши велику кількість учительських кадрів» (Кохановська О.В., 2017, с. 286).

Ключовими засадами організації та регламентації жіночої освіти стали такі документи, як «Положення про жіночі училища відомства Міністерства народної освіти» 1858 та 1860 років, «Положення про жіночі гімназії і прогімназії Міністерства народної освіти» 1870 року та «Положення 1869 р. про жіночі гімназії та прогімназії для губерній Київської, Подільської, Волинської, Вітебської та Могильовської». Останні два положення з деякими змінами ввійшли до Зводу законів Російської імперії і регламентували так звані міністерські жіночі заклади, аж доки вони не припинили своє існування (Сухенко Т. В., 2001, с. 8).

На початку XX століття наслідками реформацій у системі освіти стало відкриття в Україні 1357 початкових шкіл, 3-х середніх комерційних училищ та 33 жіночих гімназій. «Навчальний режим став демократичнішим. У низці шкіл запроваджується вивчення української мови і викладання нею. 3'явилися українські підручники та граматики українською мовою. Жінкам надавалося право вступу до університетів у ролі «вільних слухачок» (Артемова Л. В., 2006, с. 217).

Результати досліджень (Днепров Э. Д., Усачева Р. Ф., 2009; Слюсаренко Н. В., 2016) показали, що на початку XX століття загальний контингент учнів жіночих гімназій й прогімназій навіть переважав кількість учнів у чоловічих гімназіях.

Проте у навчанні чоловіків і жінок спостерігалася певна різниця. Так, наприкінці XIX, як і на початку XX століття, учні жіночих та чоловічих навчальних закладів, зокрема гімназій, вивчали дисципліни, які у них викладалися, у дещо різному обсязі, а окремі предмети взагалі були вилучені із навчального плану для жіночих закладів освіти. Лише близько 
половини навчальних предметів були однаковими, а тому можна уявити, що й результати освіти та можливості щодо подальшого навчання або перспективи працевлаштування у випускників різної статі також були різні.

Про відмінності у змісті навчальних програм у гімназіях для дівчат і хлопців свідчать результати наукових розвідок В. Кузьменка, наведені в таблиці 3.

Таблиця 3

Зведені дані про вивчення навчальних предметів у чоловічих та жіночих гімназіях

\begin{tabular}{|c|c|c|c|c|c|}
\hline \multirow{3}{*}{$\begin{array}{l}\text { № } \\
\mathbf{3 / n}\end{array}$} & \multirow{3}{*}{ Навчальні дисципліни } & \multicolumn{4}{|c|}{$\begin{array}{c}\text { Загальна кількість годин на навчальні } \\
\text { дисципліни }\end{array}$} \\
\hline & & \multicolumn{2}{|c|}{ Кінець XIX ст. } & \multicolumn{2}{|c|}{ Початок XX ст. } \\
\hline & & чоловічі & жіночі & чоловічі & жіночі \\
\hline 1. & Закон Божий & 16 & 14 & 16 & 18 \\
\hline 2. & $\begin{array}{l}\text { Російська мова з церковнослов'янською і } \\
\text { логіка }\end{array}$ & 29 & - & - & - \\
\hline 3. & Російська мова & - & - & 34 & - \\
\hline 4. & Російська мова і словесність & - & 25 & - & 34 \\
\hline 5. & Латинська мова & 42 & - & 30 & - \\
\hline 6. & Філософська пропедевтика & - & - & 3 & - \\
\hline 7. & Законознавство & - & - & 2 & - \\
\hline 8. & Грецька мова & 33 & - & - & - \\
\hline 9. & Математика & 29 & 15 & 30 & 35 \\
\hline 10. & Фізика & 7 & 3 & 10 & - \\
\hline 11. & Географія & 8 & 14 & - & - \\
\hline 12. & Географія і космографія & - & - & - & 16 \\
\hline 13. & Педагогіка & - & 4 & - & 4 \\
\hline 14. & Історія & 13 & 12 & 22 & 16 \\
\hline 15. & Рукоділля & - & 14 & - & 7 \\
\hline 16. & Природнича історія і фізика & - & - & - & 14 \\
\hline 17. & Природознавство & - & 9 & 10 & - \\
\hline 18. & Французька мова & 19 & 24 & 24 & 30 \\
\hline 19. & Німецька мова & 19 & 24 & 23 & 24 \\
\hline 20. & Англійська мова & - & - & - & 7 \\
\hline 21. & Краснопис & - & 8 & 2 & 7 \\
\hline 22. & Гігієна & - & 1 & - & - \\
\hline 23. & Краснопис і малювання & 10 & - & - & - \\
\hline 24. & Малювання & - & 13 & 5 & 14 \\
\hline 25. & Співи & - & 9 & - & - \\
\hline 26. & Танці & - & 5 & - & 4 \\
\hline 27. & Гімнастика & - & - & - & 6 \\
\hline
\end{tabular}

Джерело: (Кузьменко В.В. , 2005, с. 88).

Різниця у навчальних дисциплінах для хлопців і дівчат та різний обсяг їх надання в чоловічих та жіночих гімназіях відповідно призвели до дещо різного результату й змісту їхнього навчання. Як ми бачимо, дівчата взагалі не вивчали грецьку та латинську мови, а годин на інші (французьку, німецьку) для них, навпаки, призначалося більше. Незнання ж латині, основної мови науки, сприяло звуженню їхніх можливостей для подальшого навчання в закордонних вищих навчальних закладах.

Проте більше годин надавалося таким предметам для дівчат, як малювання, танці, гімнастика, співи, рукоділля. Адже головні завдання жіночої освіти були пов'язані з реальними життєвими умовами, їх призначенням та суспільною роллю, а тому передбачали підготовку дівчат до практичного застосування отриманих знань у дорослому самостійному житті. 
Не всі реформаторські ідеї були цілком прийнятними та продуктивними для розвитку жіночої освіти. Так, багато родин навіть середнього статку не мали спроможності сплачувати за навчання. Закритий характер підготовчих класів у гімназіях, «циркуляр про кухарчиних дітей» та інші фактори дещо стримували вищезгадану реформу. Разом із тим, підкреслюємо й надзвичайне історичне її значення у другій половини XIX століття, адже вона сприяла охопленню середньою освітою більшої кількості представниць і, таким чином, надала можливості для їхньої інтеграції до різних сфер суспільного функціювання.

Серед тенденцій, що характеризували еволюцію та трансформацію змісту жіночої освіти впродовж другої половини XIX - на початку XX століття в Україні, слід відзначити ї̈ зумовленість реформами, що призвели до поступового послаблення впливу церкви на діяльність навчальних закладів разом із посиленням уваги держави до гімназійної освіти; розробки нових форм і методів навчання жінок та залучення їх до професійної освіти; регламентування жіночої освіти документацією офіційного характеру (правилами, уставами, статутами, планами, положеннями, програмами та ін.) та переважання в процесі її розвитку більш світського контексту.

Відтворена картина розвитку жіночої освіти була характерна до початку XX століття, адже події 1917 року призвели до закриття більшості жіночих навчальних закладів, що було зумовлено намаганням радянської влади зрівняти права чоловіків і жінок, у тому числі на здобуття освіти.

\section{ВИСНОВКИ ТА ПЕРСПЕКТИВИ ПОДАЛЬШИХ ДОСЛІДЖЕНЬ}

Таким чином, результати проведеного дослідження та отримані статистичні дані щодо зростання кількості закладів навчання для дівчат в Україні впродовж другої половини XIX - на початку XX століття свідчать про значний попит на жіночу освіту та заклади з її надання, у першу чергу гімназії і прогімназії.

Реформи, характерні для періоду дослідження проблеми становлення й розвитку жіночої освіти в Україні, безпосереднім чином впливали на зміст діяльності навчальних закладів для дівчат. У них формували компетентності, які безпосередньо пов'язувалися із життям, виконанням ключових для того часу гендерних ролей та певною мірою сприяли стереотипізації їх призначення у суспільстві.

Проте в системі освіти реформи майже зрівняли жіночу і чоловічу середню школу. Вони слугували «імпульсом для розвитку жіночої освіти та забезпечили значне випередження демократизації соціального складу середньої жіночої школи у порівнянні з чоловічою» (Днепров Э. Д., Усачева Р. Ф., 2009, с. 234).

Однак верхня межа дослідження, що ознаменована створенням єдиної школи для жінок і чоловіків та спільного навчання, зумовила початок нового етапу розвитку освіти в Україні. Це й окреслює перспективи наступних наукових розвідок, що полягають у розкритті теоретико-методологічних засад функціювання закладів жіночої освіти у подальші роки в Україні.

\section{СПИСОК ВИКОРИСТАНИХ ДЖЕРЕЛ}

Артемова, Л. В. (2006). Історія педагогіки освіти: підручник. К.: Либідь.

Днепров ,Э. Д., Усачева, Р. Ф. (2009). Женское образование в России. М.: Дрофа.

Кохановська, О.В. (2017). Вплив освітніх реформ на розвиток природничо-математичної освіти дівчат (початок XX ст.). Педагогічний альманах: збірник наукових праць. Херсон: КВНЗ «Херсонська академія неперервної освіти».33, $285-291$.

Кузьменко, В.В. (2005). Формування в учнів чоловічих та жіночих гімназій наукової картини світу (кінець XIX - початок XX століття). Науковий вісник Південноукраїнського державного педагогічного університету ім. К. Д. Ушинського. Спеціальний випуск «/нтеграція гендерного підходу в сучасну науку і освіту: результати та перспективи». Одеса: ПДПУ ім. К.Д.Ушинського. 84-88.

Кузьменко, В. В. (2014). Формування наукової картини світу учнів: від витоків до сьогодення: монографія. Друге вид. Херсон: КВНЗ «Херсонська академія неперервної освіти».

Національна стратегія у сфері прав людини (2015): Указ Президента України від 25 серпня 2015 p. № 501/2015. URL: https:// zakon1.rada.gov.ua/laws/show/501/2015/paran3?Lang=e

Слюсаренко, Н. В. (2016). Становлення та розвиток трудової підготовки дівчат у школах України кінця XIX - XX століття: монографія. Друге вид. Херсон: КВНЗ «Херсонська академія неперервної освіти».

Сухенко, Т. В. (2001). Середня жіноча освіта в Україні (XIX - початок XX століття).(Автореферат дисертації кандидата історичних наук ). Київ.

\section{REFERENCES}

Artemova, L. V. (2006). Istoriya pedahohiky osvity : pidruchnyk. Kyiv: Lybid'.

Dneprov, E. D., Usacheva, R. F. (2009). Zhenskoye obrazovaniye v Rossii. Moscow: Drofa.

Kokhanovs'ka, O.V. (2017). Vplyv osvitnikh reform na rozvytok pryrodnycho-matematychnoyi osvity divchat (pochatok KHKH st.). Pedahohichnyi almanakh: zbirnyk naukovykh prats. Kherson: KVNZ "Kherson Academy of Continuing Education", 33, $285-291$.

Kuz' menko, V.V. (2005). Formuvannya v uchniv cholovichykh ta zhinochykh himnaziy naukovoyi kartyny svitu (kinets' KHIKH pochatok KHKH stolittya). Naukovyi visnyk Pivdennoukrainskoho derzhavnoho pedahohichnoho universytetu im. K. D. Ushynskoho. Spetsialnyi vypusk «Intehratsiia hendernoho pidkhodu v suchasnu nauku i osvitu: rezultaty ta perspektyvy». Odesa, Ukraine: PSPU them. K.D. Ushinsky, 84-88.

Kuz' menko, V. V. Formuvannya naukovoyi kartyny svitu uchniv: vid vytokiv do s'ohodennya. Kherson, Ukraine: KVNZ «Khersonska akademiia neperervnoi osvity».

Natsional'na stratehiya u sferi prav lyudyny (2015): Ukaz Prezydenta Ukrayiny vid 25 serpnya 2015 r. № 501/2015.

Retrieved from: https://zakon1.rada.gov.ua/laws/show/501/2015/paran3?Lang=e (in Ukrainian).

Slyusarenko, N. V. (2016). Stanovlennya ta rozvytok trudovoyi pidhotovky divchat u shkolakh Ukrayiny kintsya KHIKH - KHKH stolittya. Kherson: KVNZ «Khersonska akademiia neperervnoi osvity».

Sukhenko, T. V. (2001). Serednya zhinocha osvita v Ukrayini (KHIKH - pochatok KHKH stolittya). (Avtoreferat dysertatsii kandydata istorychnykh nauk). Kyiv.

Статтю подано до редколегії 19.01 .2019 p.

Рекомендовано до друку 04.02.2019 p. 